\title{
Morphological characteristics of ovarian development of two Nile tilapia (Oreochromis niloticus) strains in mixed-culture systems
}

\author{
[Características morfológicas do desenvolvimento ovariano de duas linhagens de tilápia-do-nilo \\ (Oreochromis niloticus), em sistemas de cultivo misto] \\ P.R. Neves ${ }^{1}$, M.R.M. Natali ${ }^{1}$, R.P. Ribeiro ${ }^{1}$, L. Vargas $^{1}$, K.R. Maehana ${ }^{1}$, N.G. Marengoni ${ }^{2}$ \\ ${ }^{1}$ Universidade Estadual de Maringá \\ Avenida Colombo 5790 \\ 87020-900 - Maringá, PR \\ ${ }^{2}$ UNIOESTE - Marechal Cândido Rondon, PR
}

\begin{abstract}
This study was carried out to morphologically characterize and classify the stages of gonad development in different Nile tilapia strains (Oreochromis niloticus). Eighty-four and ninety-two ovaries from Bouaké and Chitralada strains, respectively, were evaluated at different ovarian developmental phases: initial (104 days of culture), intermediate (152 days of culture), and the final (279 days of culture). The ovaries were microscopically evaluated and submitted to histological processing and hematoxylin-eosin staining to determine their characteristics and be classified. No morphological differences in ovaries between strains were observed during the initial phase (stage A - immature). During the intermediate growing phase, higher gonad development was observed for Chitralada strain (stage B - maturation) in comparison with Bouaké strain (stage A - immature). During the final growing phase, no differences between strains were observed for morphological characteristics (stage C - mature). Despite the similarities in reproductive behavior of the Bouaké and Chitralada females at the end of the final growing phase (gain weight phase), differences for macroscopic and microscopic aspects and oocytes during the initial and intermediate growing phases of the strains were observed.
\end{abstract}

Keywords: Oreochromis niloticus, morphology, ovarian development, strain

\section{RESUMO}

Este trabalho teve como objetivo caracterizar morfologicamente e classificar os estádios de desenvolvimento gonadal de tilápias do Nilo (Oreochromis niloticus) de linhagens distintas. Foram avaliados 84 ovários da linhagem Bouaké e 92 da linhagem Chitralada, em diferentes fases de desenvolvimento: inicial (imatura - 104 dias de cultivo), intermediária (crescimento - 152 dias de cultivo) e final (ganho de peso - 279 dias de cultivo). Os ovários foram analisados macroscopicamente e submetidos a procedimento histológico, corados com hematoxilina-eosina, para determinação das características microscópicas e subsequente classificação. Não foram observadas diferenças morfológicas nos ovários entre as linhagens na fase inicial (estádio A - imaturo). Na fase intermediária, os ovários revelaram diferenças morfológicas, evidenciando maior desenvolvimento gonadal para a linhagem Chitralada, (estádio B - maturação) em relação à Bouaké (estádio A). Na fase final (ganho de peso) os ovários não apresentaram diferenças morfológicas entre as linhagens (estádio $C$ - maduro). Apesar de semelhanças no comportamento reprodutivo das fêmeas das linhagens Bouaké e Chitralada, na fase final (ganho de peso), diferenças, em relação à classificação da fase intermediária nos aspectos macroscópicos e microscópicos e diâmetro dos ovócitos, foram observadas.

Palavras-chave: Oreochromis niloticus, morfologia, desenvolvimento ovariano, linhagem

Recebido em 30 de setembro de 2008

Aceito em 3 de agosto de 2009

E-mail: patinti@yahoo.com.br 


\section{INTRODUCTION}

According to FAO (Aquaculture..., 2002), worldwide aquaculture recorded a $9.2 \%$ growth from 1970 to 2001 . In 2001, 142.1 million tons of fishes were produced (from fishery and aquaculture). This activity contributed to more than 48.4 million ton, equivalent to US\$ 61.4 billions income (Borghetti et al., 2003).

During the last years, the tilapia worldwide production was strongly influenced by the fast expansion of $O$. niloticus, cultivated in China, Philippines, Thailand, Indonesia, and Egypt (Fitzsimmons, 2000).

The fast expansion of $O$. niloticus was due to its characteristics which make it one of the fish with the greatest potential for world production in function of its productive performance and reproductive characteristics.

This species shows important characteristics: eat basic items from the trophic chain and respond with the equivalent efficiency to animal and vegetable protein intake; resistance to diseases and low dissolved oxygen levels, characterized by few spines and absence of the Yshaped ones, which are not desirable; and finally, is a very proliferous species.(Torloni, 1984; Boll et al., 1995).

The production fish system greatly depends on quantity and quality of fingerlings to attend the producers demand. For this reason, the tilapia reproduction plays a fundamental role in this process.

An important tool used for reproductive evaluation is the morphological evaluation of fish ovaries at different phases of the maturation process. Important information about the dynamic of the oocitary development and the way oocytes are released, as well as the oocytes number and sizes, are obtained during these phases. By classifying the oocyte development degrees, it is possible to establish the period of the reproduction process as well as to separate adults from youngs, and to estimate the size of the first mature oocyte (Balon, 1984).

A study of Coward and Bromage (1998) with Tilapia zilli, performed to classify the oocitary development and ovarian dynamic, revealed two phases of the gonadal development, the first called pre-vitellogenesis, related to the vitello vesicles appearance and the second one, called vitellogenesis, is completed eight days after the pre-vitellogenesis.

Phases related to ovarian development are described by many authors (Nikolski, 1963; Laevastu, 1965; Vazzoler, 1971; 1981). In general, the used scales are based on macroscopic characteristics. According to Wallace and Selman (1981), in teleost phase, four main stages of the oocitary growth are recognized; stage A (immature), stage B (in maturation), stage $\mathrm{C}$ (mature), and stage $\mathrm{D}$ (empty); but Vazzoler (1996) characterized six stages of the ovarian development.

A general application scale for females described by some authors (Nikolski, 1963; Laevastu, 1965; Vazzoler, 1971; 1981) considers as stage A (immature) when the ovaries are similar to filaments, translucent, and reduced size, placed along the dorsal wall, occupying less than $1 / 3$ of the celoma cavity, without vascularization signs, with long oviducts, with no oocytes. As stage B (in maturation), the ovaries would occupy around $1 / 3$ to $2 / 3$ of the celoma cavity, present shorter oviduct, showing intense capillary net, being possible to observe small and medium oocytes. In stage $\mathrm{C}$ (mature), ovaries occupy almost the whole celoma cavity; are turgid; large oocytes can be observed, opaque and/or translucent, whose frequency vary with the maturation progress; and the oviducts are found full of these oocytes. In the last stage, considered stage D (empty) the ovaries are found in different flabbiness degrees (depending whether it was total or partial spawning) with stretched membranes and hemorrhagic aspect; occupying, again, less than $1 / 3$ of the celoma cavity; and few oocytes can be observed (in absorption) similar to "whiten lumps".

Few studies have been carried out with tilapias, ovaries morphology of fishes at different maturation stages, and descriptions of the oocitary development phases. According to Wallace and Selman (1981), in teleost, four main stages of the oocitary growth are recognized, but Vazzoler (1996) characterized six stages in the ovarian development.

This oocitary development phase are differently named according to the authors, Vazzoler (1996) characterized the ovarian development as the 
following: Phase I - germinative young cells; Phase II - stocked oocytes; Phase III - oocytes with lipidic vitellogenesis; Phase IV - Oocytes with lipidic and proteic vitellogenesis; Phase V oocytes with complete vitellogenesis; and Phase $\mathrm{VI}$ - oocytes in hyalinization.

This study was undertaken to evaluate morphological characteristics of the ovarian development of two strains of Nile tilapia $(O$. niloticus), Bouaké and Chitralada, in mixed culture system, from the post-larvae period to the slaughter age.

\section{MATERIAL AND METHODS}

The experiment was carried out at the Experimental Station of Psciculture, at the Universidade Estadual de Maringá, UEM/CODAPAR, located in the Floriano district, Maringá - PR, from November 2003 to August 2004.

Nile tilapia fingerlings (O. niloticus) of the Bouaké strain (BOK) obtained at the Experimental Station of Pisciculture, at the Universidade Estadual de Maringá, (UEM/CODAPAR), and Chitralada strain (CHI) obtained in the Aquabel Psciculture Station (Rolândia- PR), were used in this study

One hundred seventy-six fishes, 84 from BOK strain and 92 from CHI strain, were evaluated during three phases of the growing period: initial growth phase - (at 104 days of culture); intermediate growth phase (at 152 days of culture); and final growth phase, or gain weight phase (at 279 days of culture).

In the initial phase, 36 ovaries from BOK strain and 44 from $\mathrm{CHI}$ strain were analyzed. Fishes were allocated in a facility similar to a greenhouse, $50 \%$ covered with black plastic screen and lateral plastic canvas to protect for severe climate variations and predators.

Inside the greenhouse, both BOK and CHI strain fingerlings were randomly allocated each one to nine $500 \mathrm{~L}$ asbestos cement boxes with daily water renewal of $40 \%$.

At the intermediate and final phases, 24 ovaries from both BOK and CHI strains were analyzed. During these phases, fishes of both strains were randomly allocated in 4,500L asbestos cement boxes, covered to avoid predators attack.

During the experimental period, water temperature and dissolved oxygen were daily measured, and water $\mathrm{pH}$ and conductivity were monthly recorded.

Crumble diets at the first phase and extruded $45 \%$ protein diets were used in the following phases. Fishes were fed four times a day, ad libitum, and leftovers were removed by siphonage to keep water in good conditions.

The gonadossomatic relation was calculated as gonadal weight/body weight x100 to determine the ovaries functional state.

Ovary morphological characteristics were determined according to the following methodology: gonads were placed in aqueous Bouin fixation for 12 hours and transferred to $70 \%$ alcohol to preserve the material. Further, the material was dehydrated in increased alcohol series, diaphanized in xylol and embedded in paraffin in order to obtain transversal cuts of $5 \mu \mathrm{m}$ thickness each. The ovaries were stained by the hematoxylin-eosin method.

A completely randomized experimental design with two tilapia female strains (Bouake and Chitralada) and different number of replicates per phase and strains (36 and 44; initial phase, and 24 for intermediate and final phases of the Bouaké and Chitralada strains) were used. The means of the analyzed data were compared by Fisher test at a significance level of 5\%, using the SAEG program (Euclydes, 1983).

Ovaries morphology was evaluated by an Olympus CBA optical microscope, to measure the diameter using micrometric ocular lens. The stage classification of the gonadal development was performed according to the methodology described by Vazzoler (1996).

The photographic documentation was performed by an image capture system using the Motic B5 Profissional 3.0 microscope.

\section{RESULTS}

The water quality during the experimental period was controlled according to the recommended patterns of aquaculture (Boyd, 1990; Popma and 
Phelp, 1998).The following means of water temperature $\left({ }^{\circ} \mathrm{C}\right), \quad \mathrm{O}_{2} \mathrm{D} \quad(\mathrm{mg} / \mathrm{L}), \quad \mathrm{pH}, \quad$ and conductivity $(\mathrm{mS} / \mathrm{cm})$ were recorded during the experimental period: $21.25 \pm 3.92 ; 5.35 \pm 1.62$; $7.92 \pm 0.82 ; 167.94 \pm 18.25$, respectively.

No morphological differences in ovaries from BOK and CHI strains for macro and micro characteristics were observed during the initial growth phase (104-day-fingerlings)

The ovaries occupied less than 1/3 of the celoma cavity of the animal; showed reduced size; delicate filaments, with translucent aspect; and the oocytes were not observed.

The microscopic analysis showed a conjunctive tissue capsule with large number of oocytes with small diameter, surrounded by rare collagen fibers and blood vessels.

Two kinds of oocytes were morphologically distinguished. One, less frequent, constituted by rounded and medium diameter oocytes averaged $28.41 \pm 3.47 \mu \mathrm{m}$ to BOK strain and $23.64 \pm 2.74 \mu \mathrm{m}$ to CHI strain. A light and central nucleus, with two or three basophilic nucleolus was observed and the cytoplasm was rare and basophilic (Fig. 1).

The second kind, predominantly, showed an average diameter $100.23 \pm 9.46 \mu \mathrm{m}$ to $\mathrm{BOK}$ strain and $87.50 \pm 4.97 \mu \mathrm{m}$ to $\mathrm{CHI}$ strain, with polygon shape. Multiple nucleolus presented central and peripheral localization, the cytoplasm was slightly more basophilic and developed, surrounded by pavement follicular cells (Table 1; Fig. 2, 7, and 8).

The morphological characteristics observed at this phase allowed classify these fingerlings ovaries, independently of the strain, as immature and the oocytes in stage A (immature), being the oocytes at the chromatin-nucleolar stage (Phase1) and perinuclear stage (Phase 2).

During the intermediate growth phase, at 152 days, differences between the strains were observed for macroscopic evaluation of ovaries.

The BOK strain showed larger ovaries in comparison to those ovaries of the previous phase, occupied about $1 / 3$ of the celomatic cavity, and showed consistent filamentous shape.
They present whiten lumps, being possible to evidence small oocytes and blood vessels. The ovaries of the $\mathrm{CHI}$ strain were clearly larger than those from the BOK strain and occupied up to $2 / 3$ of the celomatic cavity, the external part of the reproductive organs was well characterized with slightly yellow color, intense vascularization, and medium oocytes observed by naked-eye.

At histological analysis, the ovary of the BOK strain showed a thicker conjunctive tissue capsule with oocytes of different sizes. Less oocytes at cromatine-nucleolar stage with predominance of oocytes at that phase were found.

During this phase, some oocytes acquired follicle characteristics as long as new structures appeared. The nucleolus was always placed at the nucleous periphery, with basophilic cytoplasm, which presented uniformed lipidic vesicles mainly concentrated at the periphery. Coupled to the oocytes, appeared a cellular and acidophilic membrane, named vitelline membrane which was enclosed by two or three follicular cells layers that got a cubic shape (Fig. 9).

Some of these oocitary follicles reached a medium diameter 247.82 $\pm 6.062 \mu \mathrm{m}$ characterizing the initial maturation phase, it means, oocytes with vitelline vesicle formation (Phase 3). But the predominance of oocytes still at the perinuclear phase (Phase 2) would classify them as immature and at stage A (Table 1).

A CHI strain was histologically characterized at this developmental stage by presenting simultaneous occurrences of oocytes in several oocytary phases (Fig. 4), perinuclear oocytes, oocytes with vitelline membrane, (Fig 3) and presence of some oocytes with lipidic and proteic vitellogenesis (Fig. 5).

Oocytes with lipidic and proteic vitellogenesis showed an average diameter of $351.77 \pm 3.99 \mu \mathrm{m}$ and were characterized by presenting acidophilic cytoplasm full with lipidic and proteic vesicles (acidophilic platleps). The vitelline membrane became thicker and the follicular cells (granulous) increased in size and number. The nuclear membrane became more irregular (Table 1). 
The oocytes presented vitelline membrane formation (Phase 3) and lipidic and proteic vitellogenesis (Phase 4), suggesting the $\mathrm{CHI}$ ovaries would be in the initial maturation period (stage B), with evidences of a higher gonadal development in comparison to the BOK strain, despite the same culture period.

No morphological differences between BOK and $\mathrm{CHI}$ strains were observed during the final phase (gain weigh phase), at 279 days of culture.

The ovaries of both strains occupied $2 / 3$ of the celomatic cavity, showed yellow color, intense vascularization, and large oocytes, which could be easily observed.

In these ovaries, there was a predominance of well developed ovarian follicles with an average diameter $855.68 \pm 11.23 \mu \mathrm{m}$ for BOK strain and $665.62 \pm 11.58 \mu \mathrm{m}$ for CHI strain and they occupied almost the whole ovarian stroma (Table 1).
These follicles were characterized by presenting oocytes of increased size in relation to the previous stages, cytoplasm fulfilled by proteic vitelline vesicles making it extremely acidophilic, and absence of lipidic vesicles. Surrounded by this cytoplasm, the radiate zone was found, characterized by transversal strips and surrounding the follicular cells organized in distinct layers forming teaks. Irregular or absent nucleus (Fig. 6 and 10) were also observed.

These characteristics were similar for both strains allowing to infer that at 279 days of culture, the ovaries showed oocytes with complete vitellogenesis (Phase 5), being considered as mature (stage $\mathrm{C}$ ).

The oocytes diameter of Bouaké and Chitralada strains at different developmental phases, initial growth (104 days of culture), growing (152 days of culture) and gain weight phase (279 days of culture) are showed in Table 1.

Table 1. Oocytes diameter means of Bouaké (BOK) and Chitralada (CHI) strains at different developmental phases; initial (104 days of culture), intermediate growth (152 days of culture), and final growth (279 days of culture)

\begin{tabular}{ccc}
\hline Developmental phase (days) & BOK & CHI \\
& $(\mu \mathrm{m})$ & $(\mu \mathrm{m})$ \\
\hline 104 & $100.23 \pm 9.46 \mathrm{a}$ & $87.50 \pm 4.97 \mathrm{~b}$ \\
152 & $247.82 \pm 6.062 \mathrm{~b}$ & $351.77 \pm 3.99 \mathrm{a}$ \\
279 & $855.68 \pm 11.23 \mathrm{a}$ & $665.62 \pm 11.58 \mathrm{~b}$ \\
\hline
\end{tabular}

Means in the same line followed by distinct letters are statistically different $(\mathrm{P}<0.05-$ Fisher test $)$.

The gonadossomatic relation (GSR), which expresses the percentage the gonads represent to the total weight or body weight, is a good indicator of the ovaries functional stage, due to the strict relation between the advance of the oocytary maturation process, increase in the volume and, consequently, the ovaries weight (Vazzoler, 1996).

In the present study, no difference between Bouaké and Chitralada strains for GSR was found $(\mathrm{P}>0,05)$. For fishes at intermediate growing phase, the GSR values were 0.82 for
BOK and 1.367 for CHI strains, and at the final growing phase, the GSR values were 1.065 for BOK and 1.547 for CHI strains. (Table 2). During the initial phase, no GRS values were obtained because it was not possible to measure the gonads.

Gonadossomatic mean value for Bouaké and Chitralada strains at different developmental phases, intermediate growing (152 days of culture) and final growing (279 days of culture) are presented in Table 2.

Table 2. Gonadossomatic relation mean for Bouaké (BOK) and Chitralada (CHI) strains at different developmental phases, intermediate growing (152 days of culture) and final growing (279 days of culture)

\begin{tabular}{ccc}
\hline Gonadossomatic relation & BOK & CHI \\
\hline 152 & $0.82 \mathrm{a}$ & $1.367 \mathrm{a}$ \\
279 & $1.065 \mathrm{a}$ & $1.547 \mathrm{a}$ \\
$\mathrm{CV}(\%)$ & 28 & 19 \\
\hline
\end{tabular}

Means in the same line followed by distinct letters are statistically different $(\mathrm{P}<0.05$ - Fisher test). 

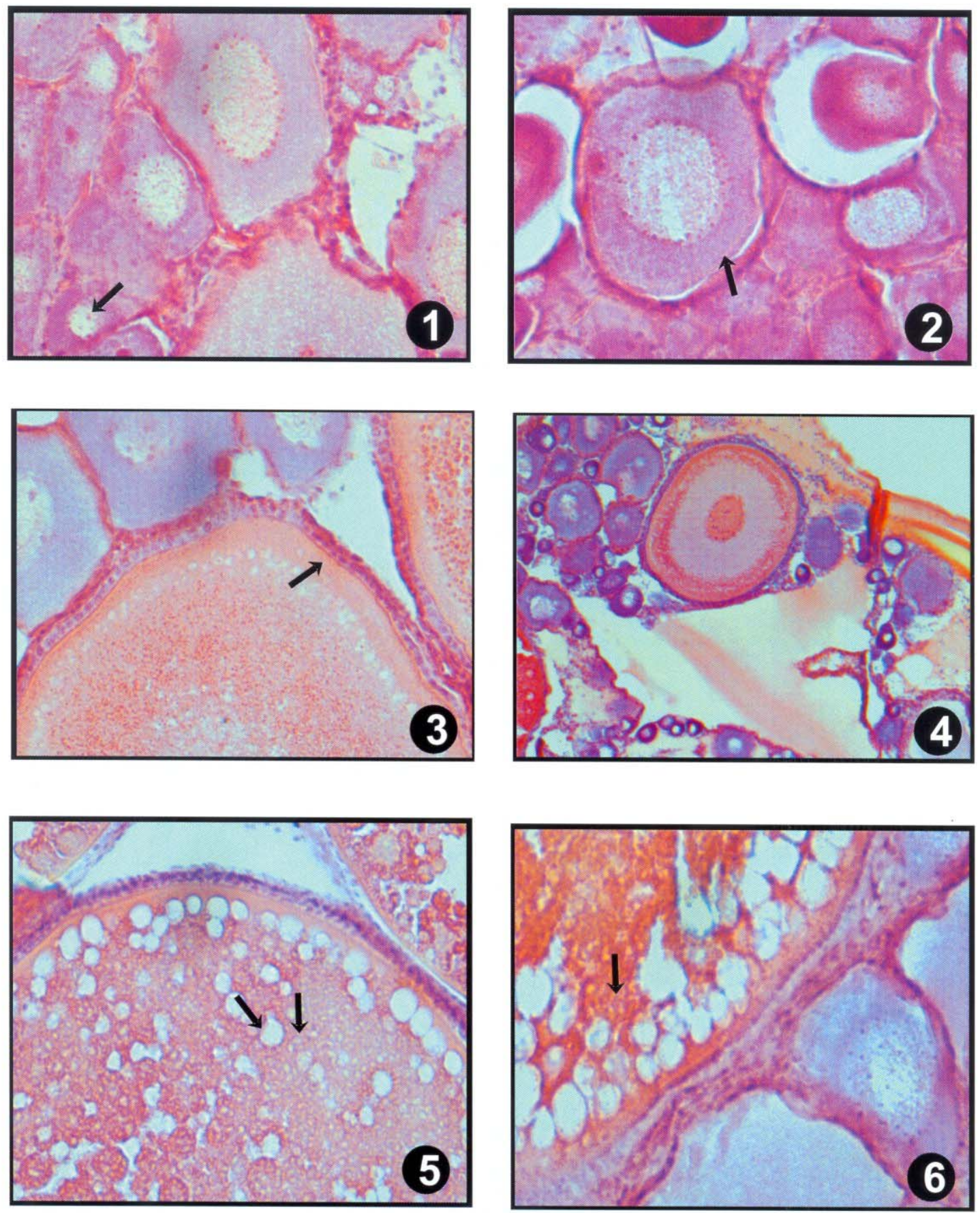

Figures 1 and 2. Tilapia ovary of Chitralada strain at 104 days of culture; 1: oocytes at chromantinnuclear phase; 2 : oocytes at perinuclear phase. $(\longrightarrow)$. HE-40x.

Figures 3, 4, and 5. Tilapia ovary of Chitralada strain at 152 days of culture; 3 : vitelline membrane; 4: occurrence of oocytes at different oocitary phases; 5: oocytes with lipidic and proteic vitellogenesis $(\longrightarrow)$. HE-40x.

Figure 6. Tilapia ovary of Chitralada strain at 279 days of culture, oocytes with proteic vitellogenesis $(\longrightarrow) . H E-40 x$. 

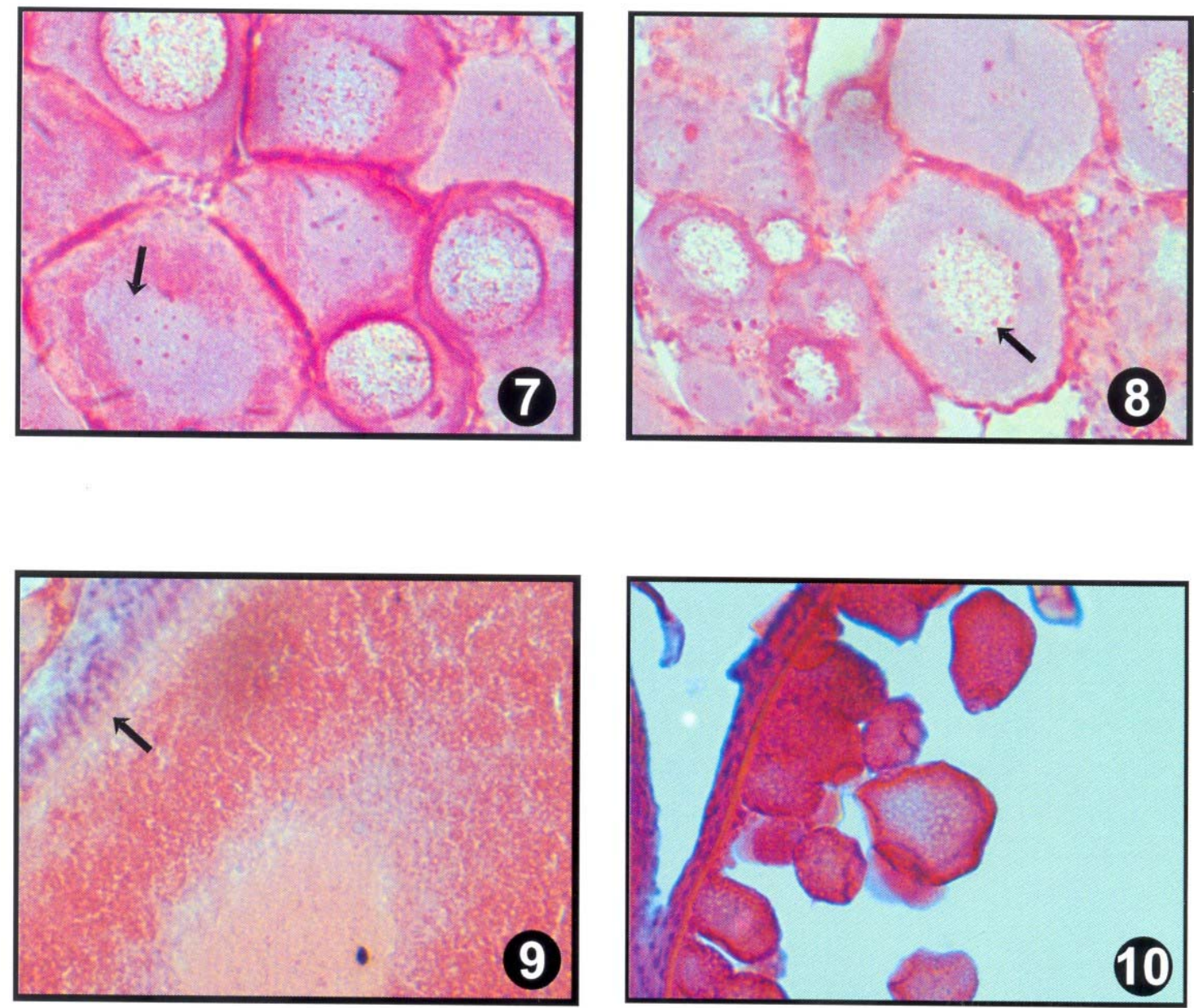

Figures 7 and 8. Tilapia ovary of Bouaké strain at 104 days of culture; 7: oocytes at perinuclear phase $(\longrightarrow)$, with nucleus in the central position; 8: oocytes at perinuclear phase $(\longrightarrow$ ), with nucleolus at the nucleus periphery. HE-40x.

Figure 9. Tilapia ovary of Bouaké strain at 152 days of culture, oocytes appearance with vitelline membrane formation $\longrightarrow$. HE-40x.

Figure 10. Tilapia ovary of Bouaké strain at 279 days of culture, mature oocytes (stage C), with empty follicle. HE-40x.

\section{DISCUSSION}

Macroscopic aspects observed at the initial growing phase (104 days of culture) allowed to classify the ovaries as immature. Similar results were found by Narahara (1991) and Vazzoler (1996) for teleost fishes.

Takashima and Hibiya (1995) highlighted that the characteristics of ovaries from all teleosts are similar considering the morphological and functional aspects having, as basic unit, the ovarian follicle.

Microscopic results in the present study confirmed the ovary macroscopic characteristics once oocytes were found at cromatine-nuclear (phase 1) and perinuclear (phase 2) stages which, independently of the strain, were classified as stage A (immature).

Similar results in the present study were found relative to the structural aspects observed by Wallace and Selman (1981) and Vazzoler (1996) in the determination of the cellular dynamic aspects of the oocytes growth in teleosts, that describes the oocytes cellular characteristics as oocytes at cromatine-nuclear and perinuclear stages.

The cellular characteristics of the ovaries of Bouaké and Chitralada strains during the first 
growing phase (at 104 days of culture) have already been defined and were identified.

Oguri and Yoshikawa (1978) carried out a research to study sexual differentiation and gonadal morphology in Tilapia zilli at different days of culture and observed that at 25 days of culture, it was possible to distinguish the oocytes at the perinuclear phase, which occupied almost the whole ovary; besides considering that at 80 days of culture, vitellogenesis begins, suggesting that this species presents higher gonadal development in comparison to Nile tilapia. The relation between culture period and gonadal development differs between gender and species.

According to Bromage and Coward (1999), the tilapias spawning cycles tend to be very asynchronous which results in variations in gonadal development, even in the same lot.

Later development was evidenced by Satoh (1974), who verified the germinative cells initiate the differentiation at 24 days of culture for Oryzias latipes.

During the intermediate growing phase, the oocytes from Bouaké strain remained at stage A, despite the increased in diameter. The predominant cellular characteristic was the oocytes which remained at perinuclear phase and the ovaries were smaller.

In the Chitralada strain, the ovaries were remarkably larger, yellow, histologically presenting oocytes at different oocitary phases, perinuclear oocytes, oocytes with vitelline membrane, and presence of some oocytes with lipidic and proteic vitellogenesis.

The average diameter of the largest follicles, whose oocytes presented lipidic and proteic vitellogenesis, was $351.77 \pm 3.99 \mu \mathrm{m}$. This value is in agreement with the descriptions for the initial maturation (stage B), showing higher gonadal development in the CHI strain in comparison to the BOK strain, despite the same culture period.

The best reproductive condition of the $\mathrm{CHI}$ strain relative to $\mathrm{BOK}$ strain during the intermediate growing phase (152 days of culture) was also observed for the reproductive development of the variables (weight and body length, weight gain, and length)
Wagner et al. (2004), evaluating the productive performance of four tilapias strains from Nilo (intraspecific hybrid, Bouaké, and Chitralada $1^{\text {st }}$ and $2^{\text {nd }}$ generation) at different growing phases, observed better productive performance for Chitralada strain, based on weight gain, carcass weight, and apparent food conversion in comparison to the Hybrid strain (HIB) and Bouaké.

The low reproductive performance of BOK strain is probably due to endogamy in this strain which was introduced in the country 30 years ago with a lot of only 60 fishes (Moreira, 2000).

Pullin and Capili (1988), in a study carried out in Asia with stocked tilapias, also reported low reproductive performance of fishes due to low number of introduced tilapias.

During the final phase (279 days of culture), no differences between strains were observed for gonad development and reproductive behavior.

The ovaries from both species were macro and microscopically classified as stage C (mature), showing oocytes with complete vitellogenesis (phase 5).

There was a strong predominance of overdeveloped ovarian follicles for both BOK and $\mathrm{CHI}$ strains which occupied practically the whole ovarian stroma. The oocytary diameter for BOK and CHI strains in this study were larger than those found by Miranda et al. (1999) in a study involving two teleost species ( $A$. bimaculatus lacustris and $L$. reinhardti) to evaluate the gonadal development stage. In the first species, the follicles at vitellogenesis stage showed diameter $486.42 \mu \mathrm{m}$ and $606.94 \mu \mathrm{m}$ for the second one, reinforcing gonad development differences between the species.

On the other hand, no difference between the strains during the final growing phase suggests the BOK strain recovered the reproductive performance at this phase.

The strains showed similarly behavior during the final growing phase for the GSR.

According to Vazzoler (1996), the GSR is an indicative of ovaries function, because of the strict relationship between oocytary maturation 
process advance and volume, and consequentially, weight of ovaries.

Navarro et al. (2006), studying lambari silver (Astayanax scabripinnis) in several culture systems, observed differences in the gonadossomatic relation. This relation was lower for females in mixed culture than for females separately cultivated. The authors suggest this is due to a better efficiency in the use of energy in the reproduction process.

When the morphological characteristics of ovary and gonad development stages were analyzed together, it was possible to conclude the Bouaké and Chitralada fishes at the final phase of the growing system (at 279 days of mixed culture) were mature and ready to spaw. Also, fish larvae were present on the surface of the tanks, without hormonal stimuli.

For Wallace and Selman (1981), the maturation stage finishes, for most fishes, when oocytes accomplish their total development in size reaching to the maturation phase and ovulation, after appropriate hormones stimulation.

The captivity condition responsible for follicular atresia is reported by several authors. In a study with two teleosts species, Miranda et al. (1999), found that $A$. bimaculatus lacustris, teleost with partial spawning and bred in tanks, had spontaneous spawning while the other species, $L$. reinhardti, despite reaching the maturation period, demanded artificial induction to initiate the spawning. Both strains of the present study bred in captivity, did not show any atresic oocytes.

\section{CONCLUSIONS}

The female reproductive behavior of Bouake and Chitralada strains can vary according to the growing phase and days of culture. The mixed culture during 279 days allowed similar reproductive behavior for both strains and spontaneous spawning occurrence.

\section{REFERENCES}

AQUACULTURE statistic. Roma: FAO, 2002. Disponível em: $<$ http://www.fao.org/> Acessado em 5 jan. 2004.

BALON, E.K. Patterns in the evolution of reproductive styles in fishes. In: POTTS, G.W.; WOOTON R.J. (Eds). Fish Reproduction: strategies and tactics. London: Academic Press, 1984. p.35-53.

BOLL, M.G.; SATO, G.; AMARAL JUNIOR, H.A. Resultados preliminares de método alternativo de manejo da tilápia, Oreochromis niloticus, no período de inverno em regiões de clima subtropical. In: ENCONTRO BRASILEIRO DE AQUICULTURA, 3.,1995, Ibirubá. Anais... Porto Alegre: UFRS, 1995. p.88-93.

BORGHETTI N.R.B.; OSTRENSKY A.; BORGHETTI J.R. Aquicultura, uma visão geral sobre a produção de organismos aquáticos no Brasil e no mundo. Curitiba: Grupo Integrado de Aquicultura e Estudos Ambientais, 2003. 128p.

BOYD, C.E. Water Quality in Ponds for Aquaculture. Alburn, Al: Alburn University, 1990. 482p.

BROMAGE, N.R.; COWARD, K. Spawning frequency, fecundity, egg size and ovarian histology in groups of Tilapia zilli maintained upon two distinct food ration sizes from first-feeding to sexual maturity. Aquat. Living Resour., v.12, p.1122, 1999.

COWARD, K.; BROMAGE, N.R. Histological classification of oocyte growth and the dynamics of ovarian recrudescence in Tilapia zilli. J. Fish Biol., v.53, p.285-302, 1998.

EUCLYDES, R.F. Manual de utilização do programa SAEG. Viçosa: UFV, 1983.

FITZSIMMONS, K. Future trends of tilapia aquaculture in the Americas. In: COSTA-PIERCE, B.A.; RAKOCY, J.E. (Eds). Tilapia Aquaculture in the Americas. Baton Rouge: World Aquaculture Society, 2000. p.252-264.

LAEVASTU, T. Manual of methods in fishery biology. Research of fish stocks. FAO, Manual Fish. Sci., 1965, n.1, fasc.5, sect.4. 51p.

MIRANDA A.C.L.; BAZZOLI N.; RIZZO E. et al. Ovarian follicular atresia in two teleost species: a histological and ultrastuctural study. Tissue \& Cell, v.31, p.480-488, 1999.

MOREIRA, H.L.M.; DELLAGOSTIN O.A.; ERDTMANN, B. et al. Levels of inbreeding and relatedness in breeder stocks of Nile tilapia (Oreochromis niloticus) detected by microsatellite analysis. In: TILAPIA AQUACULTURE IN THE $21^{\text {a }}$ CENTURY, 1., 2000, Rio de Janeiro. Proceedings... Rio de Janeiro, 2000. v.1, p.59-67.

NARAHARA, M.Y. Histofisiologia do ovário de teleósteo. In: SEMANA SOBRE HISTOLOGIA DE PEIXES DA FCAV-UNESP, 1991, Jaboticabal. Anais... Jaboticabal: FUNEP, 1991, p.39-46. 
NAVARRO R.D.; SILVA R.F.; FILHO O.P.R. et al. Comparação morfometrica e índices somáticos de machos e fêmeas do lambari prata (Astayanax scabripinnis Jerenyns, 1842) em diferentes sistemas de cultivo. Zootec. Trop., v.24, p.165-176, 2006.

NIKOLSKY, G.V. The ecology of fishes. London: Academic Press, 1963. 352p.

POPMA, T.J.; PHELPS, R.P. Status report to commercial tilapia producers on monosex fingerling productions techniques. In: AQUICULTURA BRASIL, 10., 1998, Recife. Anais...Recife: ABRAq, 1998, p.127-145.

PULLIN, R.S.V.; CAPILI, J.B. Genetic Improvement of tilapias: problems and prospects. In: PULLIN, R.S.V.; BRHUKASWAN, T.; TONGUTHAI, K. et al. (Eds). The second International Symposium on Tilapia in Aquaculture. Bangkok: ICLARM, 1988. p.259-266.

SATOH, N. An ultrastructural study of sex differentiation in the teleost Oryzias latipes $J$. Embryol. Exp. Morph., v.32, p.195-215, 1974.

TAKASHIMA, F.; HIBIYA, T. Gonads. In: TAKASHIMA, F.; HIBIYA, T. An Atlas of Fish Histology - Normal and Pathological Features. 2.ed. Tokyo: Kondansha Ltd., 1995, p.128-153.
TORLONI, C.E.C.; GALLI, L.F. Criação de peixes. São Paulo: Nobel, 1984.

VAZZOLER, A.E.A.M. Diversificação fisiológica e morfológica de Micropogon furnieri (Desmarest, 1822), ao sul de Cabo Frio, Brasil. Bol. Inst. Oceanog., v.20, p.1-70, 1971.

VAZZOLER, A.E.A.M. Manual de Métodos para estudos biológicos sobre populaçãoes de peixes. Crescimento e Reprodução. Brasília: CNPq/Programa Nacional de Zoologia, 1981. 108p.

VAZZOLER, A.E.A.M. Biologia da reprodução de peixes teleósteos: teoria e prática. Maringá: EDUEM, São Paulo, 1996. 169p.

WAGNER P.M.; RIBEIRO P.R.; MOREIRA M.L.H. et al. Avaliação do desempenho produtivo de linhagens de tilápia do Nilo (Oreochromis niloticus) em diferentes fases de criação. Acta Scien., v.26, p.187-196, 2004.

WALLACE, R.A.; SELMAN, K. Cellular and dynamic aspects of oocytes growth in teleosts. Am. Zool., v.21, p.325-343, 1981.

YOSHIKAWA, H.; OGURI, M. Sex differentiation in a cichlid, Tilapia zilli. Bull. Jpn. Soc. Sci. Fish., v.44, p.313-318, 1978. 